\title{
Incidental occurrence of papillary renal cell carcinoma in the native kidney with autosomal dominant polycystic kidney disease after renal transplantation: A case report
}

\author{
MAHMOUD ABBAS $^{1}$, MELANIE PÄTZEL ${ }^{2}$, ANGELIKA THURN ${ }^{1}$, \\ OLAF ANSELM BRINKMANN $^{2}$ and OLAF BETTENDORF ${ }^{1}$ \\ ${ }^{1}$ Institute of Pathology and Cytology, D-48465 Schüttorf; \\ ${ }^{2}$ Urology Department, Bonifatius Hospital, D-49808 Lingen, Germany
}

Received January 22, 2021; Accepted July 13, 2021

DOI: $10.3892 / \mathrm{mco} .2021 .2386$

\begin{abstract}
Autosomal dominant polycystic kidney disease (ADPKD) is one of the best-known genetic diseases. Almost half of the patients with ADPKD will develop end-stage renal disease, and the majority of patients are treated with renal transplantation. The current study presents a case that developed papillary renal cell carcinoma (PRCC) in the native right kidney 10 years after renal transplantation. PRCC is a not common malignant tumour entity $(18.5 \%$ of all cases of renal cell carcinoma) compared with common clear cell renal carcinoma (65-70\% of all cases of RCC).
\end{abstract}

\section{Introduction}

Diagnosis of renal cell carcinoma in cases with polycystic kidney diseases may be difficult and often delayed despite the use of contrast-enhanced computed tomography (CT) and magnetic resonance imaging (MRI) (1). The presence of multiple and irregular sized cysts with haemorrhage and pain and maybe infection play a role in rendering early diagnosis of renal cell carcinoma. Autosomal dominant polycystic kidney disease is the most common autosomal dominant hereditary renal disease, which frequently leads to end-stage renal disease, necessitating dialysis during or after the sixth decade of life. The estimated prevalence of ADPKD is 1 in 1,000-2,500 individuals (2).

\section{Case presentation}

A 72-year-old patient, height $180 \mathrm{~cm}$, weight $81 \mathrm{~kg}$, BMI 25 (normal weight), with end-stage renal disease due to autosomal polycystic kidney disease (ADPKD) received a living kidney

Correspondence to: Dr Mahmoud Abbas, Institute of Pathology and Cytology, 14 Techniker Strasse, D-48465 Schüttorf, Germany E-mail: mahabbas74@gmail.com

Key words: papillary renal cell carcinoma, autosomal dominant polycystic kidney disease, renal transplantation, incidental case graft. No history of long-standing analgesics. The patient has a history of nicotine abuse ( 25 cigarettes per day). The family history of the patient revealed that the father, one sister and the grandparents of the patient have not suffered from any tumours or kidney diseases. The mother and another sister have suffered from polycystic kidney disease. The patient underwent haemodialysis from 2006 until the date of transplantation. After that, he received a transplanted kidney in the right iliac fossa in November 2010. No coronary angiography and no renal functions before transplantation. Preoperatively he suffered from renal anaemia, hypertension, ischaemic heart disease and multiple severe arterial and arteriolar atherosclerosis. Concomitantly, he suffered from arachnoid cyst, multiple aneurysms in the carotid artery and in the cerebral vessels. He had also multiple liver cysts and colonic diverticulosis. He had developed renal hyperparathyreoidismus in 2009 . He received parathyroidectomy with reimplantation in the neck muscle (sternocleidomastoideus muscle). There is no nephrectomy of the suffered native kidney because there were no medical issues. 8 years after transplantation he developed squamous cell carcinoma in the skin of the face. Recently in November 2020, he has developed sustained right renal pain and pressure symptoms.

In the clinical examination of the patient, there were bad general conditions with reduced weight and renal pain. The ultrasonography showed polycystic kidneys at both sides. There was a suspected cystic lesion in the right kidney. The transplanted right kidney was normal. The computer tomography showed haemorrhagic renal cyst in the right kidney, which was $10 \mathrm{~cm}$ in diameter (Fig. 1). Preoperatively, there are no available Computer tomography. The examination of the urine showed excessive RBCs. The laboratory results showed normal renal functions of the transplanted kidney. At this point, there was a clinical indication of nephrectomy in the right side for the polycystic native kidney. In the gross pathology, there were multiple cysts with thin rim of kidney tissue in-between the cysts. One cyst in the lower pole was large, $\sim 20 \mathrm{~cm}$ in diameter with solid area of $\sim 4 \mathrm{~cm}$ in diameter (Fig. 2). The microscopic examination showed a papillary renal cell carcinoma (PRCC-type 1) of the right polycystic kidney, $\sim 4 \mathrm{~cm}$ in 


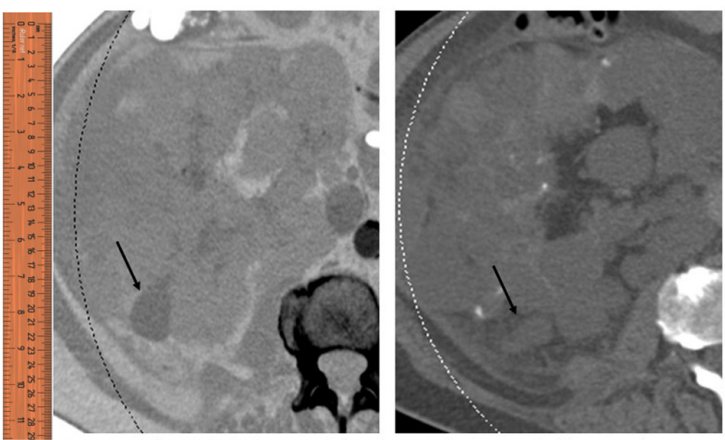

Figure 1. Right kidney with large cystic lesion in the lower pole. Multiple cysts in the kidney of a patient with autosomal dominant polycystic kidney disease. A large cyst in the lower pole with friable brown lining tissue (arrows indicate the cyst).

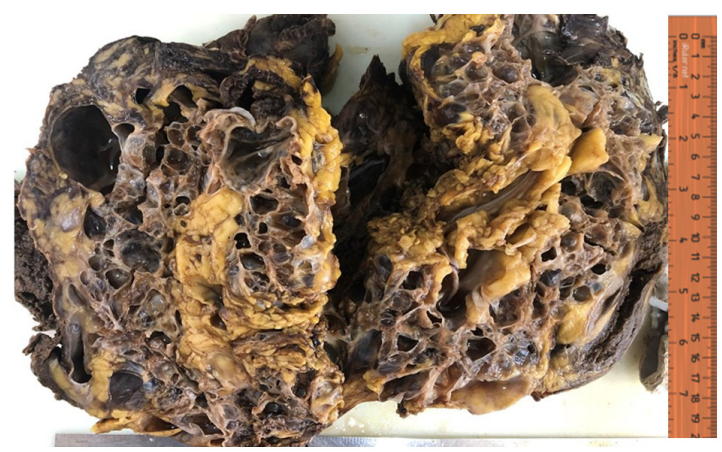

Figure 2. Right native kidney with polycystic kidney disease. Computer tomography captured images of the large cyst in the lower pole with friable tumour tissue and haemorrhage, surrounded by multiple cysts with smooth lining.

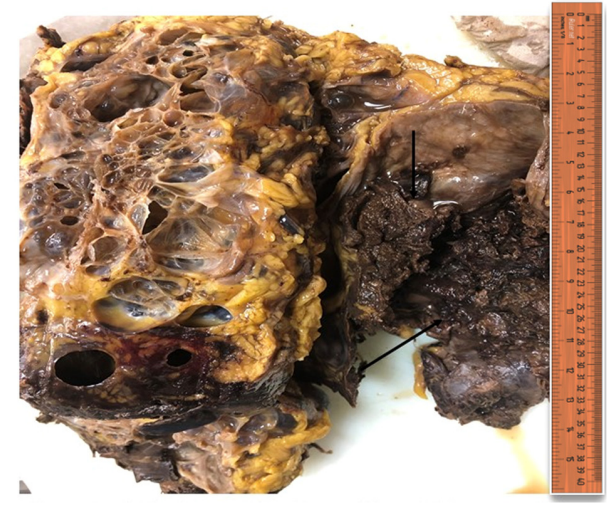

Figure 3. Right native kidney with polycystic kidney disease. Lower pole after cutting revealed a large cystic tumour and brown friable tissue inside the cyst (arrows indicate the cyst).

diameter, which incorporated in the large cyst (Fig. 3). After completing microscopic examination, there is only stage pT1a (Fig. 4) without metastasis and with complete resection (R0). PRCC has traditionally been subdivided into two types. Type 1 carcinomas have papillae covered by cells with nuclei arranged in a single layer, however, Type 2 carcinomas have nuclear pseudostratification, often high nuclear grade with abundant eosinophilic cytoplasm $(1,2)$.

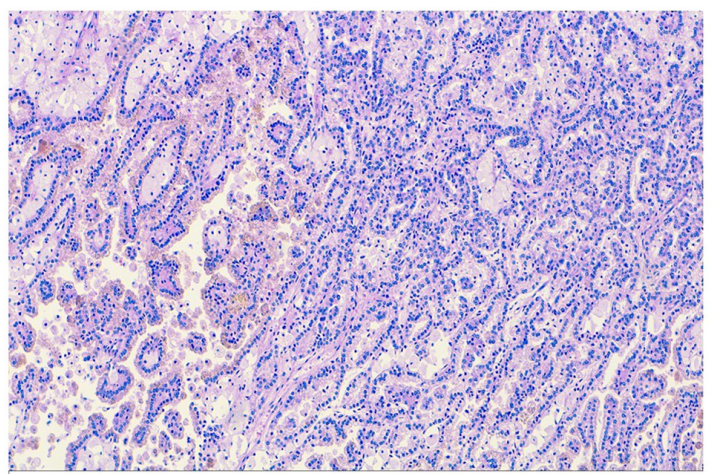

Figure 4. Histological stain of papillary renal cell carcinoma, type 1 and low-grade (G1). Sample was taken from the tumour tissue from the cyst in the lower pole. Staining was performed using haematoxylin and eosin.

Postoperatively, there were no signs of metastasis in the body. The transplanted kidney is well functioning.

\section{Discussion}

Almost half of the patients with ADPKD will develop end-stage renal disease (3). There are accepted indications of nephrectomy in ADPKD cases, such as recurrent pyelonephritis, cyst haemorrhage requiring repeated transfusions, pain refractory to medical management and massively enlarged kidneys that cause pressure symptoms of the organs in the true pelvis or mechanical pressure with reduced blood supply of the transplanted kidney $(4,5)$. There is overall increased tendency of malignancy after transplantation (6). A total of 5\% of all malignancies after transplantations are kidney tumours, twice the amount of that in the general population (7). After kidney transplantation, there is detectable increased risk (15-fold) of developing renal cell carcinoma ( $\mathrm{RCC})(8,9)$. Among these tumours, there is increased incidence $(40 \%)$ to develop papillary renal cell carcinoma after transplantation compared to prevalence of only $10-15 \%$ in the general population $(10,11)$. This is obviously because of the wide and expanded use of ultrasound and computer tomography in the hospitals (12).

A particular attention should be given for patients with ADPKD after transplantation, to exclude early tumours. Previous studies (Table I) have revealed that organ-confined RCCs, especially those smaller than $4 \mathrm{~cm}$ in diameter (pT1a), could be completely cured by partial or total nephrectomy but RCCs more enlarged than $7 \mathrm{~cm}$ in diameter (pT2) require an adequate tumour-free waiting period after surgery $(13,14)$.

Not only is there a risk of developing RCC in the native kidney but also in the transplanted kidney as we already presented in a previous work (15). We have supposed, that there are many sustained risk factors in these patients such as smoking, obesity and abuse of analgesics as well as prolonged use of high-dosage immunosuppressive therapy after transplantation which enhance the formation of tumours $(6,16)$.

Tumours under $4 \mathrm{~cm}$ are difficult to be detected in the native polycystic kidney and there is important need of screening and close follow-up of these patients with urine analysis, ultrasonography and computer tomography. With persistent symptoms such as side pain or haematuria, a 
Table I. Previous case reports and works from 1993-2016.

\begin{tabular}{|c|c|c|c|c|c|c|}
\hline Case report & Year & Age, years & Sex & Maximum size, $\mathrm{cm}$ & Pathological subtype & (Refs.) \\
\hline Sulser et al & 1993 & 37 & M & 4 & PRCC & (23) \\
\hline \multirow{3}{*}{ Keith et al } & \multirow{3}{*}{1994} & 31 & M & 7 & $\mathrm{CCC}$ & \multirow{3}{*}{ (1) } \\
\hline & & 44 & F & 6 & $\mathrm{CCC}$ & \\
\hline & & 62 & $\mathrm{~F}$ & N.A. & Sarcomatoid RCC & \\
\hline Gatalica et al & 1994 & 44 & M & N.A. & PRCC & (24) \\
\hline Soderdahl et al & 1997 & 63 & M & 4.5 (multifocal) & CCC, PRCC & (25) \\
\hline Jürgensen et al & 1999 & 72 & F & N.A. & $\mathrm{CCC}$ & (26) \\
\hline Hama et al & 2005 & 66 & F & N.A & $\mathrm{CCC}$ & (27) \\
\hline Lang et al & 2005 & 47 & M & 4.8 & N.A. & (28) \\
\hline Kato et al & 2007 & 56 & M & N.A & CCC, PRCC & (29) \\
\hline Chang et al & 2007 & 58 & M & 8 (bilateral) & CCC, PRCC & (30) \\
\hline Chang et al & 2009 & 58 & $\mathrm{~F}$ & 4 & $\mathrm{CCC}$ & $(31)$ \\
\hline Zeile et al & 2011 & 47 & M & 3.6 & $\mathrm{CCC}$ & $(32)$ \\
\hline Misumi et al & 2012 & 57 & M & 1 & PRCC type 2 & (33) \\
\hline $\mathrm{Na}$ et al & 2012 & 45 & M & 6 (multifocal) & CCC, PRCC & (34) \\
\hline \multirow[t]{2}{*}{ Konosu-Fukaya et al } & \multirow[t]{2}{*}{2013} & 58 & M & 7 & PRCC type 1 & \multirow[t]{2}{*}{ (35) } \\
\hline & & 32 & M & 1 & PRCC type 1 & \\
\hline Ito et al & 2014 & 67 & $\mathrm{~F}$ & 3 & $\mathrm{CCC}$ & (36) \\
\hline Zhang et al & 2016 & 73 & F & 3.4 & PRCC type 2 & (37) \\
\hline Nezu et al & 2016 & 47 & F & 3.6 & $\mathrm{CCC}$ & (38) \\
\hline
\end{tabular}

M, male; F, female; PRCC, papillary renal cell carcinoma; CRCC, clear renal cell carcinoma.

nephrectomy should be performed. There is also an elevated risk of late-onset kidney cancer $(17,18)$ and also in studies that included recipients of other transplanted organs $(19,20)$, which is not well understood.

In conclusion, this case and our previously published cases (15) demonstrate from the clinical point of view the importance and urgent development of a screening method including clinical examination, urine analysis, ultrasonography $(21,22)$ and computer tomography in short intervals for detecting and monitoring not only the transplanted kidneys but also to exclude the malignancy of both native and transplanted kidneys as well as to early detect the malignant tumours to enhance better outcome without metastasis. From the histopathological point of view, there is the need to deal macroscopically with the surgically removed kidney with care and insisting on dissecting the kidney in thin sections (5-10 mm thick) to detect small tumours within the heavy large tissue of a polycystic kidney, which is normally above $4 \mathrm{~kg}$ weight.

\section{Acknowledgements}

We would like to thank Miss Sandra Minns (Institute for Pathology and Cytology, Schüttorf, Germany) for proofreading the manuscript.

\section{Funding}

No funding was received.

\section{Availability of data and materials}

The datasets used and/or analysed during the current study are available from the corresponding author on reasonable request.

\section{Authors' contributions}

MA performed diagnosis and assisted in the collection of data, writing and publishing. MP assisted in the collection of clinical data and coordination. AT performed diagnosis and sampling. $\mathrm{OAB}$ assisted in the coordination and collection of clinical data. OB assisted in diagnosis of the case, and proof-read and wrote the manuscript. All authors have read and approved the final manuscript. MA and OB confirm the authenticity of all the raw data.

\section{Ethics approval and consent to participate}

Not applicable.

\section{Patient consent for publication}

Written informed consent was obtained from the patient for publication.

\section{Competing interests}

The authors declare that they have no competing interests. 


\section{References}

1. Keith DS, Torres VE, King BF, Zincki H and Farrow GM: Renal cell carcinoma in autosomal dominant polycystic kidney disease. J Am Soc Nephrol 4: 1661-1669, 1994

2. Cornec-Le Gall E, Alam A and Perrone RD: Autosomal dominant polycystic kidney disease. Lancet 393: 919-935, 2019.

3. Headhunt B and Elbe JN: Papillary renal cell carcinoma: A clinicopathologic and immunohistochemical study of 105 tumors. Mod Pathol 10: 537-544, 1997.

4. Delahunt B, Elbe JN, Mc Credie MR, Bthwaite PB, Stewart JH and Bilous AM: Morphologic typing of papillary renal cell carcinoma: Comparison of growth kinetics and patient survival in 66 cases. Hum Pathol 32: 590-595, 2001.

5. Parfrey PS, Bear JC, Morgan J, Cramer BC, McManamon PJ, Gault MH, Churchill DN, Singh M, Hewitt R, Somlo S, et al: The diagnosis and prognosis of autosomal dominant polycystic kidney disease. N Engl J Med 323: 1085-1090, 1990.

6. Sulikowski T, Tejchman K, Zietek Z, Rózański J, Domański L, Kamiński M, Sieńko J, Romanowski M, Nowacki M, Pabisiak K, et al: Experience with autosomal dominant polycystic kidney disease in patients before and after renal transplantation: A 7-year observation. Transplant Proc 41: 177-180, 2009.

7. Rayner BL, Cassidy MJ, Jacobsen JE, Pascoe MD, Pontin AR and van Zyl Smit R: Is preliminary binephrectomy necessary in patients with autosomal dominant polycystic kidney disease undergoing renal transplantation? Clin Nephrol 34: 122-124, 1990.

8. Morath C, Mueller M, Goldschmidt H, Schwenger V, Opelz G and Zeier M: Malignancy in renal transplantation. J Am Soc Nephrol 15: 1582-1588, 2004.

9. Penn I: Primary kidney tumours before and after renal transplantation. Transplantation 59: 480-485, 1995.

10. Kasiske BL, Snyder JJ, Gilbertson DT and Wang C: Cancer after kidney transplantation in the United States. Am J Transplant 4: 905-913, 2004

11. Suson KD, Sausville JE, Sener A and Phelan MW: Native nephrectomy for renal cell carcinoma in transplant recipients. Transplantation 91: 1376-1379, 2011.

12. Schwarz A, Vatandaslar S, Merkel S and Haller H: Renal cell carcinoma in transplant recipients with acquired cystic kidney disease. Clin J Am Soc Nephrol 2: 750-756, 2007.

13. Hoshida Y, Tsukuma H, Yasunaga Y, Xu N, Fujita MQ, Satoh T, Ichikawa Y, Kurihara K, Imanishi M, Matsuno T and Aozasa K: Cancer risk after renal transplantation in Japan. Int J Cancer 71: 517-520, 1997.

14. Mihara S, Kuroda K, Yoshioka R and Koyama W: Early detection of renal cell carcinoma by ultrasonographic screening-based on the results of 13 years screening in Japan. Ultrasound Med Biol 25: 1033-1039, 1999.

15. Patard JJ, Shvarts O, Lam JS, Pantuck AJ, Kim HL, Ficarra V, Cindolo L, Han KR, De La Taille A, Tostain J, et al: Safety and efficacy of partial nephrectomy for all T1 tumors based on an international multicenter experience. J Urol 171: 2181-2185, 2435, 2004.

16. Thompson RH, Leibovich BC, Cheville JC, Webster WS, Lohse CM, Kwon ED, Frank I, Zincke H and Blute ML: Is renal sinus fat invasion the same as perinephric fat invasion for pT3a renal cell carcinoma? J Urol 174: 1218-1221, 2005.

17. Gerth HU, Pohlen M, Thoennissen NH, Suwelack B Pavenstädt HJ, Störkel S, Abbas M, Spieker T and Thölking G: Two papillary renal cell carcinomas of different origin following renal transplantation (Case report). Oncol Lett 4: 80-82, 2012.

18. Engels EA, Pfeiffer RM, Fraumeni JF, Kasiske BL, Israni AK, Snyder JJ, Wolfe RA, Goodrich NP, Bayakly AR, Clarke CA, et al: Spectrum of cancer risk among US solid organ transplant recipients. JAMA 306: 1891-1901, 2011.

19. Alexander MP, Farag YM, Mittal BV, Rennke HG, Tullius SG and Singh AK: De novo multifocal renal cell carcinoma in the renal allograft. Kidney Int 75: 111-114, 2009.

20. Karami S, Yanik EL, Moore LE, Pfeiffer RM, Copeland G, Gonsalves L, Hernandez BY, Lynch CF, Pawlish K and Engels EA: Risk of renal cell carcinoma among kidney transplant recipients in the United States. Am J Transplant 16: 3479-3489, 2016.

21. Collett D, Mumford L, Banner NR, Neuberger J and Watson C: Comparison of the incidence of malignancy in recipients of different types of organ: A UK Registry audit. Am J Transplant 10: $1889-1896,2010$
22. Bennett WM, Simonich EL, Garre AM, McEvoy KM, Farinola MA and Batiuk TD: Renal cell carcinoma in renal transplantation: The case for surveillance. Transplant Proc 49: 1779-1782, 2017.

23. Sulser T, Fehr JL, Hailemariam S, Briner J and Hauri D: Papillary renal cell carcinoma associated with autosomal dominant polycystic kidney disease. Urol Int 51: 164-166, 1993.

24. Gatalica Z, Schwarting R and Petersen RO: Renal cell carcinoma in the presence of adult polycystic kidney disease. Urology 43: 102-105, 1994.

25. Soderdahl DW, Thrasher JB and Hansberry KL: Bilateral renal cell carcinoma in autosomal dominant polycystic kidney disease. A case report and literature review. Am J Nephrol 17: 96-99, 1997.

26. Jürgensen JS, Müller V, Kettritz U, Woywodt A, Göbel U and Luft FC: A malignant 'incidentaloma' in a patient with autosomal dominant polycystic kidney disease. Nephrol Dial Transplant 14: 490-492, 1999.

27. Hama Y, Kaji T, Ito K, Hayakawa M, Tobe M and Kosuda S: Erythropoietin-producing renal cell carcinoma arising from autosomal dominant polycystic kidney disease. Br J Radiol 78: 269-271, 2005.

28. Lang EK and Davis R: Autosomal dominant polycystic disease with renal cell carcinoma. J Urol 173: 987, 2005.

29. Kato T, Takahashi Y, Nakane K, Yokoi S, Ehara H, Shinoda I and Deguchi T: Bilateral renal cell carcinoma associated with polycystic kidney disease: Case report and literature review. Hinyokika Kiyo 53: 117-119, 2007 (In Japanese).

30. Chang YL, Chung HJ and Chen KK: Bilateral renal cell carcinoma in a patient with autosomal dominant polycystic kidney disease. J Chin Med Assoc 70: 403-405, 2007.

31. Chang MY, Chen YM, Chen YC, Tian YC, Fang JT and Yang CW: Concurrent renal cell carcinoma and central nervous system lymphoma in a patient with autosomal dominant polycystic kidney disease. Med Princ Pract 18: 486-489, 2009.

32. Zeile M, Andreou D, Poellinger A, Tunn PU and Dudeck O: Identification of the primary tumour with the help of diffusion-weighted MRI in a patient with autosomal dominant polycystic kidney disease and metastatic renal cell carcinoma. $\mathrm{Br}$ J Radiol 84: e142-e145, 2011.

33. Misumi T, Ide K, Onoe T, Banshodani M, Tazawa H, Teraoka Y, Hotta R, Yamashita M, Tashiro H and Ohdan H: Incidental renal cell carcinoma presenting in a renal transplant recipient with autosomal dominant polycystic kidney disease: A case report. J Med Case Rep 6: 154, 2012.

34. Na KY, Kim HS, Park YK, Chang SG and Kim YW: Multifocal renal cell carcinoma of different histological subtypes in autosomal dominant polycystic kidney disease. Korean J Pathol 46: 382-386, 2012.

35. Konosu-Fukaya S, Nakamura Y, Fujishima F, Kasajima A, Takahashi Y, Joh K, Ikeda Y, Ioritani N, Watanabe M and Sasano H: Bilateral papillary renal cell carcinoma and angiomyolipoma in the patients with autosomal dominant polycystic kidney disease: Case report of two cases and literature review. Pol J Pathol 64: 303-307, 2013.

36. Ito K, Asano T, Tominaga S, Yoshii H, Sawazaki H and Asano T: Erythropoietin production in renal cell carcinoma and renal cysts in autosomal dominant polycystic kidney disease in a chronic dialysis patient with polycythemia: A case report. Oncol Lett 8: 2032-2036, 2014.

37. Zhang W, Tan AY, Blumenfeld J, Liu G, Michaeel A, Zhang T, Robinson BD, Salvatore SP, Kapur S, Donahue S, et al: Papillary renal cell carcinoma with a somatic mutation in MET in a patient with autosomal dominant polycystic kidney disease. Cancer Genet 209: 11-20, 2016.

38. Nezu K, Sakai T, Kuromoto A, Kanno H, Sato M, Numahata K and Hoshi S: A case of autosomal dominant polycystic kidney disease (ADPKD) with metastases from bilateral small renal cell carcinoma. Hinyokika Kiyo 62: 313-316, 2016 (In Japanese).

This work is licensed under a Creative Commons Attribution-NonCommercial-NoDerivatives 4.0 International (CC BY-NC-ND 4.0) License. 